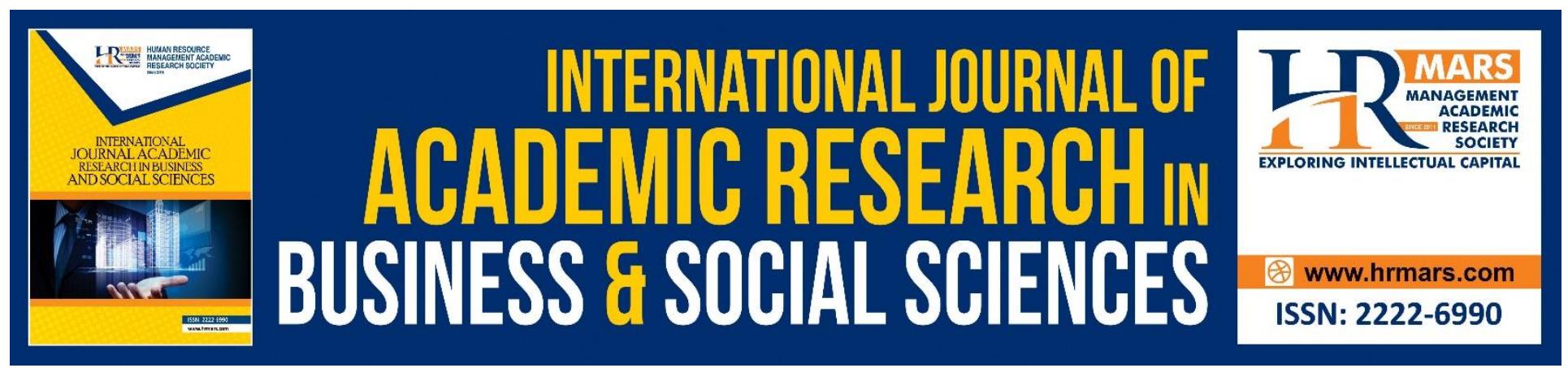

\title{
The Contributing Sources for Sustainable Funding in Malaysian Social Welfare Group
}

Nurliana Zahira Zaharrudin, Azzarina Zakaria, Siti Halijjah Shariff

To Link this Article: http://dx.doi.org/10.6007/IJARBSS/v8-i11/5576

DOI: $10.6007 /$ IJARBSS/v8-i11/5576

Received: 07 Nov 2018, Revised: 02 Dec 2018, Accepted: 30 Dec 2018

Published Online: 12 Jan 2019

In-Text Citation: (Zaharrudin, Zakaria, \& Zakaria, 2018)

To Cite this Article: Zaharrudin, N. Z., Zakaria, A., \& Zakaria, A. (2018). The Contributing Sources for Sustainable Funding in Malaysian Social Welfare Group. International Journal of Academic Research in Business and Social Sciences, 8(11), 2111-2121.

Copyright: (C) 2018 The Author(s)

Published by Human Resource Management Academic Research Society (www.hrmars.com)

This article is published under the Creative Commons Attribution (CC BY 4.0) license. Anyone may reproduce, distribute, translate and create derivative works of this article (for both commercial and non-commercial purposes), subject to full attribution to the original publication and authors. The full terms of this license may be seen

at: http://creativecommons.org/licences/by/4.0/legalcode

Vol. 8, No. 11, 2018, Pg. 2111 - 2121

http://hrmars.com/index.php/pages/detail/IJARBSS

JOURNAL HOMEPAGE

Full Terms \& Conditions of access and use can be found at http://hrmars.com/index.php/pages/detail/publication-ethics 


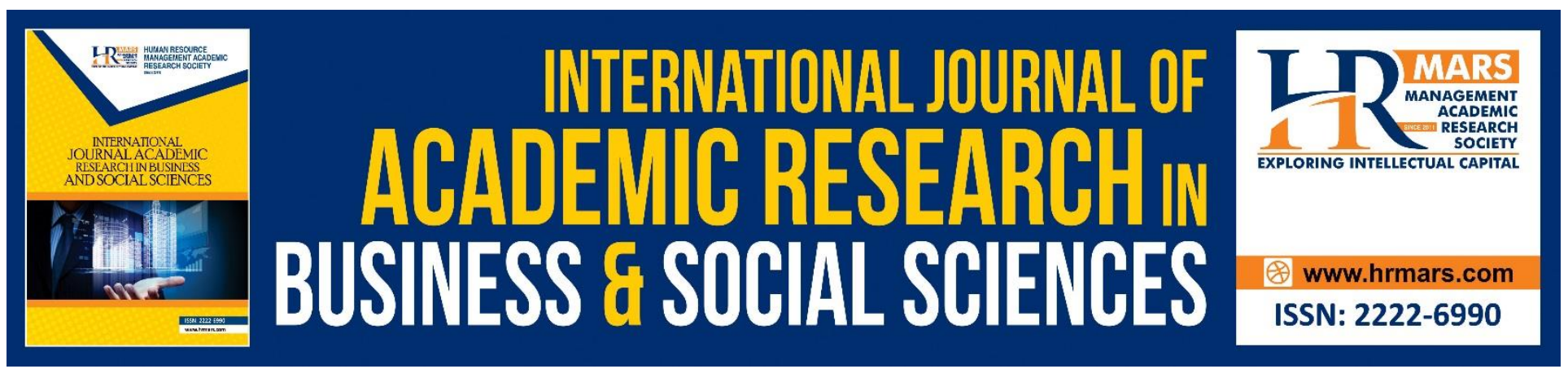

\title{
The Contributing Sources for Sustainable Funding in Malaysian Social Welfare Group
}

\author{
Nurliana Zahira Zaharrudin ${ }^{1}$, Azzarina Zakaria ${ }^{2}$, Siti Halijjah Shariff ${ }^{3}$ \\ Faculty of Business and Management, Universiti Teknologi MARA, 40450 Shah Alam, Selangor Darul \\ Ehsan, Malaysia
}

\begin{abstract}
Background: This study in progress intends to identify the relationship between donor, beneficial programme and commercialisation to sustainable funding for social welfare group (SWG) in Malaysia. The study suggests that the funding sources can contribute to the sustainable funding for social welfare group. In Malaysia, non-government organisations (NGOs) including the SWG depend significantly on government fund to survive. However, the challenging of gaps and barriers to acquiring funding considerably troubled the sustainable funding goal. Therefore, the SWG should seek for various strategies to generate sustainable funding, potentially leading to long term success. Keywords: Non- Government Organizations (NGOs), Social welfare group, Sustainable funding, Donor, Beneficial programme, Commercialisation
\end{abstract}

\section{Introduction}

During the past two decades, non-government organisations (NGOs) have increased profiles and have been in development at both national and international levels (Lewis \& Kanji, 2009). The primary forms of NGOs activities are to deliver the essential services to people in need and organise policy advocacy and public campaigns for change (Lewis, 2010). In a wide range, NGOs become active in more specialised roles such as human rights work, cultural preservation, policy analysis, environmental activism, democracy building, conflict resolution, research development and information provision (Werker and Ahmed, 2008; Lewis and Kanji, 2009). There are three significant terms commonly used for NGOs in the global arena including (1) non-profit, (2) voluntary and (3) civil society organisation (Clarke, 1998). However, the term NGO is widely used across countries including Malaysia, when the declaration was made by the United Nation (UN) in 1945 (Lewis and Kanji, 2009).

In Malaysia, the NGO is the third largest sector in the world after the public and private sector (Roslan, Arshad \& Mohd Pauzi, 2017). NGOs are essential to the government, private sector and societies (Gemmill and Bamidele-Izu, 2002). At this view, NGOs might support and collaborate with the government by developing various national programmes and prospering societies (Clark, 1993). For example, the Ministry of Higher Education (MOHE) has introduced the Malaysia Education 
Blueprint (MEB) 2015-2025, where the higher education system improve from university education to technical and vocational education and training (TVET). This programme provides equal educational opportunities for the disabled people. At this point, the Malaysian SWG will support and they might collaborate to implement the programmes since the SWG is experienced in providing activities for people with disability. Hence, the government will achieve its objective by the support from SWG. Therefore, this is proof that NGOs are essential for the government entirely.

On the other hand, NGOs also provide a positive impact to private sectors. At this point, the private sector commonly involves in Corporate Social Responsibility (CSR) programmes (Werner, 2009; Mohd Salleh, Muhamad and Mohd Roffeei, 2017). Generally, CSR programmes are mostly focusing on the aspect on protecting the environment, employees welfare, being ethical in daily business activities and improving the society's quality of life (Mohd Nasir et al., 2015). Some of the private sectors need NGOs to be involved in the CSR since the private sector is a profit-oriented company (Teegen, Doh and Vachani, 2004). So, some of them are unable to commit to the social activities at large. The existence of NGOs might support any social programmes that were unable to be noticed by the private sector. Therefore, NGOs are essential to encourage private sector activities accordingly.

Malaysian NGOs are grouped into eight categories such as regional, social welfare, community service, youth and sports, culture and arts, human rights, environmentalists and education and research (Alatas, 2003). The roles of each group are different based on their respective nature and objective. (Kamaruddin, Pawson \& Kingham, 2013). Most of the previous studies were commonly focused on emergency relief, environmentalism, health and education (Thrandardottir, 2012; Abdullah et al., 2014; Abdul Aziz, 2016). However, there is a small scale study being done on SWG in the Malaysian context (Bakri et al., 2016). Therefore, this study intends to focus on Malaysian SWG as a subject matter.

Moreover, the previous studies show that there are some barriers related to Malaysian SWG including lack of government recognition and incentives, budget deductions and limitation of social work improvements (Schwarzer et al., 2016). Based on these barriers, Bromideh (2011) claims that NGOs commonly have an issue on funding. The funding for NGOs is limited, and the possibility for NGOs to run their operation might be hindered (Parks, 2008). Therefore, NGOs are unable to plan their activities for the long term (Viravaidya and Hayysen, 2001). Regarding these matters, the possibility for NGOs to terminate their operations are high (Banks, Hulme and Edwards, 2015). Hence, this study intends to identify the sources for sustainable funding. Later, Mulroy (2003) argues as cited by Omeri (2015) there are three sources of funding which are (1) donor, (2) beneficial programmes and, (3) commercialisation that could determine the success of sustainable funding for NGOs.

\section{Literature Review}

\section{Sustainability}

Sustainability concerned on the aspirations of humankind towards a better life and known as a normative concept about how humans should act with nature, and how they are responsible for each other and future generations (Keeble, 1988; Kuhlman and Farrington, 2010). Regardless of this definition, the concept of sustainability is commonly emphasises on the long-term aspect and achieving equity between the present and future generations (Holden, Linnerud and Banister, 2014). 
INTERNATIONAL JOURNAL OF ACADEMIC RESEARCH IN BUSINESS AND SOCIAL SCIENCES

Vol. 8, No. 11, Nov, 2018, E-ISSN: 2222-6990 @ 2018 HRMARS

Sustainability, however, involves all elements and functions of the organisation to serve all stakeholders and fulfill its mission (Bal et al., 2013). In order to address the issue of the limited funding, this study intends to highlight on funding sustainability context.

\section{Sustainable Funding}

Sustainable funding means something that is beneficial to a particular activity, being able to be there in the long term such as an organisation is financially sustainable if the core activities do not collapse if there are any constraints from the external environment (Brown \& Trout, 2016). For NGOs, sustainable funding is crucial as it enables to survive in order to continue serving its constituency. This means that that that an organization can fulfill its commitments to its donors, members and the community in which it operates, so that the groups that depend on it can trust this commitment (Weerawardena, McDonald and Mort, 2010). NGOs commonly depended on external donor funding for NGOs activities (A. Islam, 2016). The contribution from the donors is inconsistent due to the economic volatility and environment competitionand the tendency for NGOs to survive in the market is weak (Parks, 2008). However, NGOs still need donors funding to support their activities, but NGOs should provide a strategy in order to remain a strong relationship with them (C. Batti, 2014). Moreover, most of the NGOs change their pattern to acquire funding by self-funding (Khieng, 2013). This is for long-term funding sustainability (Hendrickse, 2008). Therefore, by using the sustainable funding approaches, it can lead the movement from external funding sources to the new method on acquiring funding for its sustainability. Mulroy (2003) suggests that there are two categories of funding sources commonly contributing to NGOs.

- External funding sources

- Internal funding sources

The external funding sources commonly represent the donor. While, the internal funding sources commonly represent the beneficial programmes and commercialisation (which is self-funding) (Viravaidya \& Hayysen, 2001; Khieng, 2013).

\section{Donor}

A donor can be defined as an individual or a group of people who donate something for funds or charity in monetary (money) and non- monetary (gifts) resources (C. Batti, 2014). The donors might be from the government, private and/ or public (Salamon, Sokolowski and List, 2003). At this point, the donor is a source of funding that commonly from government which support any NGOs activities (Boenigk and Scherhag, 2014). Nevertheless, the practical strategies on how to get the donation for sustainable funding still pose doubts (Mutinda and Ngahu, 2016). So, Wiggill (2014) claims, through donor relationship management (DRM), the sustainable funding for NGOs will be achievable. Waters (2009) defines DRM as managing a relationship between donor and NGOs for funding strategy. The relationship with donors is important for the development of NGOs activities and enhances the growth leading to the long term sustainability (Masdar, 2015). Moreover, NGOs also need to have a good financial management system, good leadership with integrity, educated staff with experience and implementation of strategic planning in achieving a significant of DRM (Amagoh, 2015). When NGOs and donor relationships are cultivated, NGOs should experience fewer difficulties on acquiring funding. Therefore, NGOs would be able to retain their funding entirely. 
INTERNATIONAL JOURNAL OF ACADEMIC RESEARCH IN BUSINESS AND SOCIAL SCIENCES

Vol. 8, No. 11, Nov, 2018, E-ISSN: 2222-6990 @ 2018 HRMARS

According to O'Neil (2007), NGOs and donors can develop a good communication programmes through DRM that they might build long-term relationships in order to obtain financial support continuously. The communication is not only the role in delivering the information between NGOs and the donors, but it can create trust, commitment and satisfaction, which are all crucial in increasing donor support (Shaw and Allen, 2006; O'Neil, 2007). This two-way communication within NGOs and donors proves to be very important in creating understanding within the two parties, and it will assist NGOs in identifying donors' interests and simultaneously can share the interests particularly on their needs, motivation and opinion about the organisation (Shaw and Allen 2006; Ahern and Joyaux, 2008). It would then be easier to focus on relationship building practices to create an equally beneficial exchange between the NGOs and the donors. Thus, the good communication programmes between NGOs and donors are important to build good relationship management (Matten and Moon, 2008) which will then enhance donor's loyalty in achieving for sustainable funding entirely. Next, the following section continues to discuss the internal funding sources which are beneficial programmes and commercialisation.

\section{Beneficial Programme}

A beneficial programme is a form of fund-raising managed by NGOs by organising special events to gain funding for communities (Amagoh, 2015). Through the beneficial programme, NGOs can attract government funding, the private sector and the public for donation (Tortajada, 2016). Moreover, the money can be used to recover the costs including operating costs, administrative costs and programme costs (Lewis, 2010; Omeri, 2015; Mutinda and Ngahu, 2016). In Malaysia, Kiwanis Down Syndrome Foundation (KDSF) is one of the NGOs which is committed to the welfare of children with Down Syndrome, and its primary focus on the education of children up to six (6) years old. As an example, the Kiwanis Melaka celebrates the World Down Syndrome Day (WDSD) by providing some activities such as Buddy Walk, Bubbles Fun, Hand Print Art Project, Down Syndrome Awareness Quiz and Online Photo Contest. From these activities, NGOs will get the donation from an individual, government, corporate agencies and/ or other NGOs which the NGOs open for registration to the public, provide participation due to the activities, and offer for volunteers and members in KDSF. These initiatives, therefore, enable NGOs to recover part or all costs, and it allows the public to join the activities in future.

Otherwise, through the beneficial programme, it will encourage government, corporate agencies and/ or other NGOs to participate in the programmes and create collaboration (Brinkerhoff, 2003; Zafar Ullah et al., 2006). For example, Muslim Volunteer Malaysia (MVM) is one of Malaysian NGOs that provide 'Pure Heart' activities collaboration with 'Lembaga Zakat Selangor' (government) and can acquire MVM to get funding; however, the 'Lembaga Zakat Selangor' can provide an opportunity for poor families to check the status of 'zakat' applications and apply the 'zakat' on that day. Hence, it gives the benefit to both parties (government and NGOs) through the programmes. Also, most of the time, MVM has collaboration with several agencies such as 'MOHA Group, Astro Gempak, Sekolah Kebangsaan Padang Jawa and Persatuan Tadika Islam Malaysia' for programmes implementation. Therefore, through collaboration, NGOs tend to receive funding from these agencies based on the programmes provided. Thus, NGOs might feel secure when there is involvement from other agencies, and it brings a positive image to NGOs as well. 


\section{Commercialisation}

Commercialisation is the process of managing and running something primarily for financial improvement. Commercialisation can also be defined as the organisational capabilities to develop new products and promote to the market (Kang et al., 2013). In recent years most of the NGOs move to the commercialisation activities for income generating in order to survive in the market (Khieng and Dahles, 2014). The commercialisation activities exist when NGOs decide to produce and sell goods, and provide services for profits making (Coghlan and Noakes, 2015). Khieng and Dahles (2014) also claim commercialisation is a part of a self-funding activity for NGOs to survive in the market. This is also supported from previous study by (Weerawardena, McDonald and Mort, 2010), which is the self- funding activity (commercialisation) is a significant activity for generating income. Moreover, commercialisation activities acquire NGOs to engage on market and industry analysis, product and/ or service design and development, operations and technology management and customer development, which contribute to the sustainable funding (Kerlin and Pollak, 2010). Hence, the commercialisation is a self-funding activity that became very important in recent years to secure their funding (Khieng and Dahles, 2014). In a similar vein, there are two main strategies of commercialisation in order to obtain funding, involve (1) social enterprise and (2) mass media (Aldashev and Verdier, 2009).

\section{Social enterprise}

Social enterprise refers to activities commenced in the public interest by using entrepreneurial strategies (Nicholls, 2006). To recognise the activities commenced, Gray, Healy and Crofts (2003) found and agreed with Zappala (2001) definition preferable with, social enterprise acts as a business entity where the activities are much more focused on maximising profit. Social enterprise is an entity that achieves a social mission which is the social or environmental issue that organisations need to solve by using a business model in order to bring on profits. On the other hand, social enterprise refers to NGOs activities which involve a group of communities for economic development and profit generating activities to support the government and private sectors (Gray, Healy and Crofts, 2003). In the current situation, most NGOs act as the social enterprise (i.e. opening handicraft and souvenir shops, coffee shops and restaurants as well as selling t-shirts, and publishing magazines) in order to survive in the market (Mulroy, 2003). Hence, NGOs can generate their money through social enterprise activities.

\section{Mass media}

Mass media is one of the other critical strategy for NGOs to commercialise their products and services (Vestergaard, 2009). Mass media is a channel that allows broad dissemination of information to society. The mass media includes film, recordings, radio and television broadcast, and computer and/ or internet. However, most of the important mass media tools for NGOs are television, radio and Internet which has significant impacts on attracting people for donations (Aldashev, Limardi, and Verdier, 2015). NGOs can advertise their products and programmes through these channels. Moreover, through mass media, the activities and the image of NGOs can be further strengthened in creating awareness to communities, government and private sectors (Datta, Reed and Jessup, 2013). In a similar note, the commercialisation through mass 
media can significantly generate NGOs funding, and it can support the NGOs in creating additional income (Couttenier and Hatte, 2016). This is a part of the strategy for NGOs to acquire funding via internal sources (commercialisation). This strategy, therefore at once can encourage people to participate in the programmes, and it enables NGOs to sustain their funding (Hadland and Zhang, 2012). Based on the literature reviewed, the conceptual framework is shown below:

Figure 1: Conceptual Framework

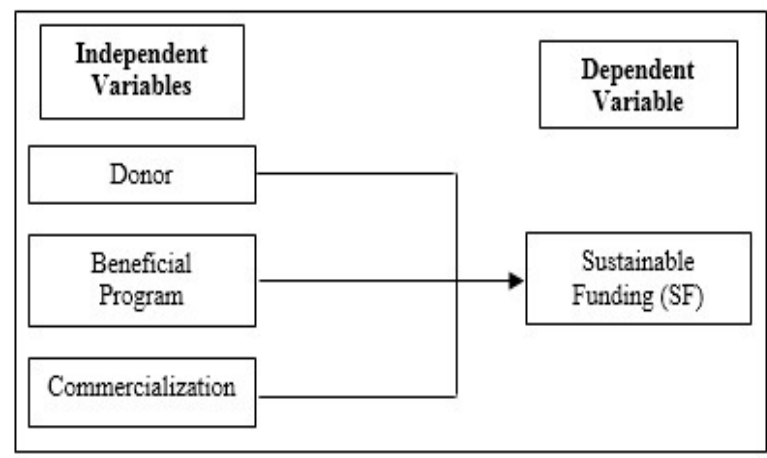

In Figure 1, the researcher proposed the conceptual framework for predicting the independent variables (IV) which include donor, beneficial programme and commercialisation that can contribute to the dependent variable (DV) that refers to the sustainable funding for the SWG in Malaysia.

\section{Conclusion}

In this paper, three sources of funding contribute to sustainable funding. Specifically, the donor, beneficial programmes and commercialisation are proposed to influence the sustainable funding for the SWG in Malaysia. However, the researcher focuses on donors first then provide beneficial programme for communities and involve in the commercialisation activities. It is suggested that, in order to build sustainable funding, NGOs in Malaysian SWG ought to refine the strategies in donor activities, beneficial programmes and commercialisation activities.

\section{Acknowledgements}

This research is funded by Institute of Research Management \& Innovation (IRMI), "Geran Inisiatif Penyeliaan (GIP): 600-IRMI/ MyRA 5/3 GIP (029/2017)," internal research grant of Universiti Teknologi MARA, Shah Alam Selangor, Malaysia.

\section{References}

Islam, A. C. (2016). Non-governmental organization vulnerabilities: Donors and resource dependence. CMC Senior Theses. Paper 1429. Retrieved from http://scholarship.claremont.edu/cmc theses/1429

Abdullah, A. N., Husain, K., Bokhari, M., Jano, Z., Kamarudin, M. F., \& Saad, M. S. M. (2014). Malaysian Environmental NGOs on the World Wide Web: Communicating campaigns through the power of photographs. Procedia - Social and Behavioral Sciences, 155, 136-140. doi:10.1016/j.sbspro.2014.10.269 
INTERNATIONAL JOURNAL OF ACADEMIC RESEARCH IN BUSINESS AND SOCIAL SCIENCES

Vol. 8, No. 11, Nov, 2018, E-ISSN: 2222-6990 @ 2018 HRMARS

Abdul Aziz, N. M. (2016). The formalisation of social engagement in the Medical Relief NGO: The evidence of MERCY Malaysia. Asian Academy of Management Journal, 21(Suppl. 1), 149-170. doi:10.21315/aamj2016.21.supp.1.7

Ahern, T and P. Joyaux, S. (2008). Keep Your Donors: The Guide to Better Communications and Stronger Relationships. Hoboken, New Jersey: John Wiley \& Sons Inc.

Alatas, S. M. (2003). The role of ngos and non-state actors in Malaysia's foreign policy formulation during the Mahathir era. Journal of Southeast Asia Social Science and Humanities, 62(1), 5984. Retrieved from ejournals.ukm.my

Aldashev, G., \& Verdier, T. (2009). When NGOs go global: Competition on international markets for development donations. Journal of International Economics, 79(2), 198-210. doi:10.1016/j.jinteco.2009.07.007

Aldashev, G., Limardi, M., \& Verdier, T. (2015). Watchdogs of the invisible hand: NGO monitoring and industry equilibrium. Journal of Development Economics, 116, 28-42. doi:10.1016/j.jdeveco.2015.03.006

Amagoh, F. (2015). Improving the credibility and effectiveness of non-governmental organizations. Progress in Development Studies, 15(3), 221-239. doi:10.1177/1464993415578979

Bakri, N. I. M., Osman, M. M., Bachok, S., \& Shuid, S. (2016). An assessment service delivery of Social Welfare Department dealing with vulnerable and disadvantages group in Perak. Procedia Social and Behavioral Sciences, 222, 203-210. doi:10.1016/j.sbspro.2016.05.148

Bal, M., Bryde, D., Fearon, D., \& Ochieng, E. (2013). Stakeholder engagement: Achieving sustainability in the construction sector. Sustainability, 5(2), 695-710. doi:10.3390/su5020695

Banks, N., Hulme, D., \& Edwards, M. (2015). NGOs, states, and donors revisited: Still too close for comfort? World Development, 66, 707-718. doi:10.1016/j.worlddev.2014.09.028

Boenigk, S., \& Scherhag, C. (2014). Effects of Donor Priority Strategy on Relationship Fundraising Outcomes. Nonprofit Management and Leadership, 24(3), 307-336. doi:10.1002/nml.21092

Brinkerhoff, J.M. (2003). Donor-funded government-NGO partnership for public service improvement: Cases from India and Pakistan. Voluntas: International Journal of Voluntary and Nonprofit Organizations, 14 (1), 105-122. doi.org/10.1023/A:1022997006704

Bromideh, A.A. (2011). The widespread challenges of NGOs in developing countries: Case studies from Iran. International NGO Journal, 6(9), 197-202. doi:10.5897/NGOJ11.014

Brown, L. K., \& Troutt, E. (2016). Funding relations between nonprofits and government: A positive example. Nonprofit and Voluntary Sector Quarterly, 33(1), 5-27. doi:10.1177/0899764003260601

Coghlan, A., \& Noakes, S. (2015). Towards an understanding of the drivers of commercialization in the Volunteer Tourism Sector. Journal Tourism Recreation Research, 37(2), 123-131. doi:10.1080/02508281.2012.11081697

Couttenier, M., \& Hatte, S. (2016). Mass media effects on non-governmental organizations. Journal of Development Economics, 123, 57-72. doi:10.1016/j.jdeveco.2016.07.001

Clark, J. (1993). The relationship between the state and the voluntary sector. Human Resource Working Paper. Retrieved from documents.worldbank.org

Clarke, G. (1998). The Politics of NGOs in South-East Asia: Participation and Protest in the Philippines. London: Routledge. 
INTERNATIONAL JOURNAL OF ACADEMIC RESEARCH IN BUSINESS AND SOCIAL SCIENCES

Vol. 8, No. 11, Nov, 2018, E-ISSN: 2222-6990 @ 2018 HRMARS

Datta, A., Reed, R., \& Jessup, L. (2013). Commercialization of innovations: an overarching framework and research agenda. American Journal of Business, 28(2), 147-191. doi:10.1108/ajb-082012-0048

Gemmill, B., \& Bamidele-Izu, A. (2002). The Role of NGOs and civil society in global environmental governance. Global Environmental Governance, 1-24. Retrieved from http://www.envnet.org/wp-content/uploads/2013/09/gemmill.pdf

Gray, M., Healy, K., \& Crofts, P. (2003). Social enterprise: Is it the business of social work? Journal Australian Social Work, 56(2), 141-154. doi:10.1046/j.0312-407x.2003.00060.x

Hadland, A., \& Zhang, S. I. (2012). The "paradox of commercialization" and its impact on media-state relations in China and South Africa. Chinese Journal of Communication, 5(3), 316-335. doi:10.1080/17544750.2012.701422

Hendrickse, R.F. (2008). Governance and financial sustainability of ngos in South Africa. University Of The Western Cape, South Africa.

Holden, E., Linnerud, K., \& Banister, D. (2014). Sustainable development: Our common future revisited. Global Environmental Change, 26, 130-139. doi:10.1016/j.gloenvcha.2014.04.006

Kamaruddin, S. M., Pawson, E., \& Kingham, S. (2013). Facilitating social learning in sustainable waste management: Case study of NGOs involvement in Selangor, Malaysia. Procedia - Social and

Behavioral Sciences, 105, 325-332. doi:10.1016/j.sbspro.2013.11.034

Kang, J., Gwon, S.-h., Kim, S., \& Cho, K. (2013). Determinants of successful technology commercialization: Implication for Korean government-sponsored SMEs. Asian Journal of Technology Innovation, 21(1), 72-85. doi:10.1080/19761597.2013.810947

Keeble, B. R. (1988). The Brundtland report: "Our common future." Medicine and war, 4(1), 17-25. doi:10.1080/07488008808408783

Kerlin, J. A., \& Pollak, T. H. (2010). Nonprofit Commercial Revenue. The American Review of Public Administration, 41(6), 686-704. doi:10.1177/0275074010387293

Khieng, S. (2013). Funding mobilization strategies of nongovernmental organizations in Cambodia. VOLUNTAS: International Journal of Voluntary and Nonprofit Organizations, 25(6), 1441-1464. doi:10.1007/s11266-013-9400-7

Khieng, S., \& Dahles, H. (2014). Resource dependence and effects of funding diversification strategies among NGOs in Cambodia. VOLUNTAS: International Journal of Voluntary and Nonprofit Organizations, 26(4), 1412-1437. doi:10.1007/s11266-014-9485-7

Kiwanis Down Syndrome Foundation(2017). World downsyndrome day 2017. Retrieved from https://www.kdsf.org.my/

Kuhlman, T., \& Farrington, J. (2010). What is sustainability? Sustainability, 2(11), 3436-3448. doi:10.3390/su2113436

Lewis, D \& Kanji, N. (2009). Non-Government Organizations and Development. London: Routledge.

Lewis D. (2010). Nongovernmental Organizations, Definition and History. International Encyclopaedia of Civil Society. New York, Springer.

Masdar, N. M. H. (2015). The practices of upward accountability in the Malaysian NGO. Procedia Economics and Finance, 31, 152-160. doi:10.1016/s2212-5671(15)01142-9 
INTERNATIONAL JOURNAL OF ACADEMIC RESEARCH IN BUSINESS AND SOCIAL SCIENCES

Vol. 8, No. 11, Nov, 2018, E-ISSN: 2222-6990 @ 2018 HRMARS

Matten, D., \& Moon, J. (2008). "Implicit" and "Explicit" CSR: A conceptual framework for a comparative understanding of Corporate Social Responsibility. Academy of Management Review, 33(2), 404-424. doi:10.5465/amr.2008.31193458

Ministry of Education Malaysia (2013). Malaysian Education Blueprint 2013-2025 (Preschool to PostSecondary Education). Retrieved from https://www.moe.gov.my/images/dasarkpm/articlefile file 003108.pdf

Mohd Nasir, N.E., Abdul Halim, N.A., Mohd Salleh, N.R., Jasni, N.S., \& Aziz, N.F. (2015). Corporate social responsibility: An overview from Malaysia. Journal of Applied Environmental and Biological Sciences, 4(10S), 82-87. Retrieved from http://researchgate.net

Mohd Salleh, N. A., Muhamad, R., \& Mohd Roffeei, S. H. (2017). CSR initiatives by companies for employees through social protection measures. SHS Web of Conferences, 34, 09002. doi:10.1051/shsconf/20173409002

Muslim Volunteer Malaysia (2017). Pure Heart Mac 2017. Retrieved from https://mvm.org.my/

Muslim Volunteer Malaysia (2017). Pure Heart 8.0 Dimeriahkan Bersama Lembaga Zakat Selangor. Retrieved from https://mvm.org.my

Mulroy, E. A. (2003). Community as a factor in implementing inter-organizational partnership: Issues, constraints and adaptations, Nonprofit Management and Leadership, 14(1): 47-66. doi: $10.1002 / \mathrm{nml} .20$

Mutinda, S. M., \& Ngahu, S. (2016). Determinants of financial sustainability for non-governmental organizations in Nakuru County, Kenya. IOSR Journal of Business and Management, 18(09), 81-88. doi:10.9790/487x-1809028188

Nicholls, A. (2006). Social Entrepreneurship: New Models of Sustainable Social Change. New York: Oxford University Press.

Omeri, K.L. (2015). Factors influencing financial sustainability of non-governmental organizations: a survey of NGOs in Nakuru Country, Kenya. International Journal of Economics, Commerce and

Management, United Kingdom, 3(9): 704-743. Retrieved from http://ijecm.co.uk/

O'Neil, J. (2007). The link between strong public relationships and donor support. Public Relations

Review, 33(1), 99-102. doi:10.1016/j.pubrev.2006.11.021

Parks, T. (2008). The rise and fall of donor funding for advocacy NGOs: Understanding the impact. Development in Practice, 18(2), 213-222. doi:10.1080/09614520801899036

Roslan, N., Arshad, R., \& Mohd Pauzi, N. F. (2017). Accountability and governance reporting by nonprofit organizations. SHS Web of Conferences, 36, 00041. doi:10.1051/shsconf/20173600041

Salamon, L.M., Sokolowski, S.W., \& List, R. (2003). Global Civil Society: an Overview. the Johns Hopkins Comparative Nonprofit Sector Project. USA: Center for Civil Society Studies

Schwarzer, B., Kämmerer-Rütten, U., Schleyer-Lindenmann, A., \& Wang, Y. (2016). Transnational Social Work and Social Welfare: Challenges for the Social Work Profession. London: Routledge.

Shaw, S., \& Allen, J. B. (2006). We actually trust the community: examining the dynamics of a nonprofit funding relationship in New Zealand. Voluntas: International Journal of Voluntary and Nonprofit Organization, 17 (3): 211-220. doi.org/10.1007/s11266-006-9018-0

Teegen, H., Doh, J. P., \& Vachani, S. (2004). The importance of nongovernmental organizations (NGOs) in global governance and value creation: An international business research agenda. Journal of International Business Studies, 35(6), 463-483. doi:10.1057/palgrave.jibs.8400112 
INTERNATIONAL JOURNAL OF ACADEMIC RESEARCH IN BUSINESS AND SOCIAL SCIENCES

Vol. 8, No. 11, Nov, 2018, E-ISSN: 2222-6990 @ 2018 HRMARS

Thrandardottir, E. (2012). What makes NGOs legitimate? An analysis of Amnesty International UK's, Greenpeace UK's and Cafod's legitimacy claims in the UK national context. The University of Manchester, Manchester.

Tortajada, C. (2016). Nongovernmental organizations and influence on global public policy. Asia \& the Pacific Policy Studies, 3(2), 266-274. doi:10.1002/app5.134

Vestergaard, A. (2009). Humanitarian branding and the media: The case of Amnesty International. Journal of Language and Politics, 7(3), 471-493. doi:10.1075/jlp.7.3.07ves

Viravaidya, M., \& Hayssen, J. (2001). Strategies to Strengthen NGO Capacity in Resource Mobilization Through Business Activities. PDA and UNAIDS Joint Publication.

Waters, R. D. (2009). Comparing the two sides of the nonprofit organization-donor relationship: Applying coorientation methodology to relationship management. Public Relations Review, 35(2), 144-146. doi:10.1016/j.pubrev.2009.01.011

Weerawardena, J., McDonald, R. E., \& Mort, G. S. (2010). Sustainability of nonprofit organizations: An empirical investigation. Journal of World Business, 45(4), 346-356. doi:10.1016/j.jwb.2009.08.004

Werner, W.J. (2009). Corporate social responsibility initiatives addressing social exclusion in Bangladesh. Journal of Health, Population, and Nutrition, 27(4): 545-562. Retrieved from https://www.ncbi.nlm.nih.gov/pmc/articles/PMC2928098/

Werker, E., \& Ahmed, F.Z. (2008). What Do Non-Governmental Organizations Do? Journal of Economic Perspectives, 22(2): 73-92. doi:10.1257/jep.22.2.73

Wiggill, M. N. (2014). Donor relationship management practices in the South African non-profit sector. Public Relations Review, 40(2), 278-285. doi:10.1016/j.pubrev.2013.10.005

Zafar Ullah, A. N., Newell, J. N., Ahmed, J. U., Hyder, M. K., \& Islam, A. (2006). Government-NGO collaboration: The case of tuberculosis control in Bangladesh. Health Policy Plan, 21(2), 143155. doi:10.1093/heapol/czj014

Zappala, G. (2001). From charity to social enterprise: managing volunteers in public-serving nonprofits. Australian Journal On Volunteering, 6 (1), 41-48. 